\title{
Lichentherapy: Highlights on the Pharmaceutical Potentials of Lichens
}

\section{Elkhateeb WA*, Elnahas MO and Daba GM}

Chemistry of Natural and Microbial Products Department, Pharmaceutical Industries Division, National Research Centre, Egypt

*Corresponding author: Waill A Elkhateeb, Chemistry of Natural and Microbial Products Department, Pharmaceutical Industries Division, National Research Centre, Dokki, Giza, 12622, Egypt, Tel: +201013241936; Fax: +20233370931; Email: waillahmed@yahoo.com

\section{Review Article}

Volume 6 Issue 2

Received Date: March 11, 2021

Published Date: April 01, 2021

DOI: $10.23880 /$ oajmb-16000190

\section{Abstract}

Lichens exist in every continent and have a history of being used as food, medicine, a source of dyes and animal feed. Lichens are now being used as natural indicators of climate change and for air quality monitoring worldwide. Lichens play an important role in many ecosystems and exist as a symbiotic association between fungi and algae or cyanobacteria. This symbiosis results in the production of unique secondary metabolites known as lichen substances, which arise within the thalli and are typically in crystal form on the surface of the fungal hyphae. Recently, lichens and their secondary metabolites have been receiving increased attention due to their nutritional value and pharmaceutical potential. This review aims to highlight on the importance and variety of common lichen substances (secondary metabolites). Finally, the commercialization of lichens is growing but, in the future, metabolic and biotechnological approaches can be used as an alternative product to overcome the limited availability of biologically active, commercially valuable and medicinally important secondary metabolite components.

Keywords: Lichens; Pharmaceutical Activities; Biological Activities

Abbreviations: BHA: Butylated Hydroxyanisole.

\section{Introduction}

Lichens play an important role in many ecosystems and exist as a symbiotic association between fungi and algae or cyanobacteria. This symbiosis results in the production of unique secondary metabolites known as lichen substances, which arise within the thalli and are typically in crystal form on the surface of the fungal hyphae. Recently, lichens and their secondary metabolites have been receiving increased attention due to their nutritional value and pharmaceutical potential [1]. Lichens can grow on a range of surfaces from rocks to existing as epiphytes on trees or leaves [2]. The majority of described lichens are terrestrial, although a few are marine and have the ability to adapt to water and saline stress. Lichens are an excellent example of a symbiotic relationship between members belonging to two unrelated separate kingdoms (fungi and algae), which results in the collection of secondary metabolites. These metabolites can be fungal originated, algal originated or unique compounds not produced by either fungi or algae individually [3].

The vegetative component of lichen is called the thallus and this can be subdivided into four main categories. Foliose: A leaf-like thallus, attached to the substrate at various points. Crustose: A thallus that is flattened against the substrate and its lower surface is entirely attached. Fruticose: the thallus is mainly composed of pendulous or, less commonly, upright branches and is attached at a single point. Squamulose: In which the thallus begins like foliose lichen, but subsequently develops erect branches named podetial [4-7]. Mostly lichens secondary metabolites have yielded a wide range of interesting compounds with biological activities from 


\section{Open Access Journal of Microbiology \& Biotechnology}

antimicrobial to anticancer. Further, the nutritional value of lichens is identified alongside a role in environmental monitoring, and several commercialized lichen-based products are located. Lichens are found on every continent and have a history of use as food, medicine, dyes, and livestock feed [1].

Approximately there are 13,500 lichen species around the world. Lichens have a history of medicinal use and beneficial claims have been correlated, to some extent, with their polysaccharide content [8]. The unique biochemical compounds produced by lichens have made them useful for people in traditional cultures as a food source, for dyes, and as medicines [9]. Lichens grow on all continents and species distribution is influenced by a range of variables, including both climate and aspect. It is estimated that lichens are the dominant vegetation on $8 \%$ of the earth's terrestrial surface. Hence, lichens are a part of many food webs; including humans, vertebrates, and invertebrates. Lichens are used as a regular food source in Africa, America, Asia, and Europe [1012].'Lichens are a valuable source of many natural classes with varying biological potentials including antiviral, antifungal, analgesic, antipyretic, antioxidant, and anticancer effects. Lichens produce a wide array of biologically active primary (intracellular) and secondary (extracellular) metabolites $[13,14]$. More than 1000 metabolites were extracted from lichens, some of these compounds are exclusively produced by lichens, while others were commonly observed in fungal extracts and those of higher plants [15]. The pharmaceutical potential of lichens is high and several companies are now attempting to commercialise these unique attributes [14]. This review aims to highlight on the importance and variety of common lichen substances (secondary metabolites), which are investigated along with their historical and modern applications, use in health research.

\section{Bioactive Compounds and Medicinal uses of Lichens}

Various lichens are well known as producers of many secondary metabolites with noticeable biological activities [16-18]. Although, many lichens are edible; other lichens are found to have some toxic substances. Different compounds produced by lichens are classified into separate groups:

- Aliphatic substances (such as acids, polyhydric alcohols, zeorin compounds, etc.);

- Aromatic substances (such as depsides, depsidones, diphenyleneoxide derivatives, quinones, xanthone derivatives, triterpenes, tetronic acids, and nitrogencontaining compounds, etc.); and

- (3) Carbohydrates (mainly polysaccharides). Up to date, about 350 different secondary metabolites produced from lichens have been identified. The majority of lichen's secondary metabolites water-insoluble and thus these metabolites can be extracted by organic solvents. Among the important substances that have been produced by lichens and identified are depsides (e.g., diffractic acid), dibenzofurans, lactones (e.g., protolichessterinic acid), phenolic compounds (e.g., atranol and resorcinol), pulvinic acid derivative (e.g., vulpinic acid), and usnic acids (e.g., usnic acid). Other lichen substances have been also frequently studied including atranorin, lecanoric acids, stictic acid, and pannarin [19-21]. Figure 1 presents the chemical structures of some lichens compounds.

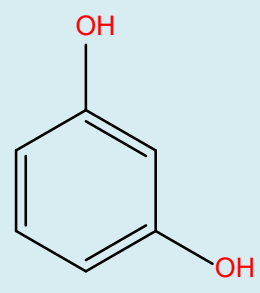

Atranol

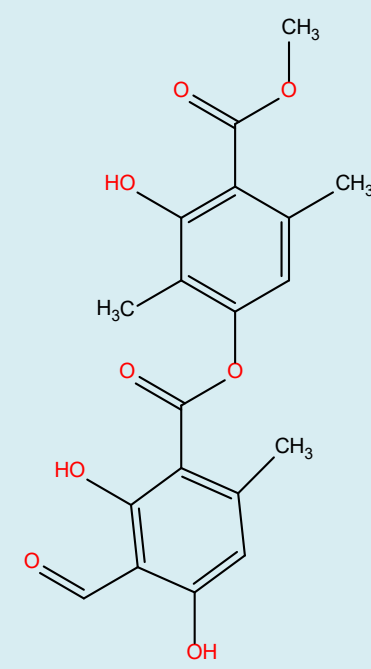

Atranorin

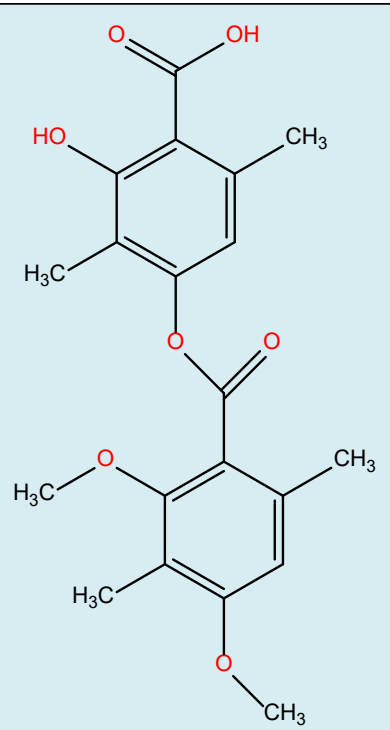

Diffractic acid 


\section{Open Access Journal of Microbiology \& Biotechnology}<smiles>Cc1cc(OC(=O)c2c(C)cc(O)cc2O)cc(O)c1C(=O)O</smiles>

Lecanoric acid<smiles>COc1cc(C)c2c(c1C)OC(=O)c1c(C)c(Cl)c(O)c(C=O)c1O2</smiles>

Pannarin

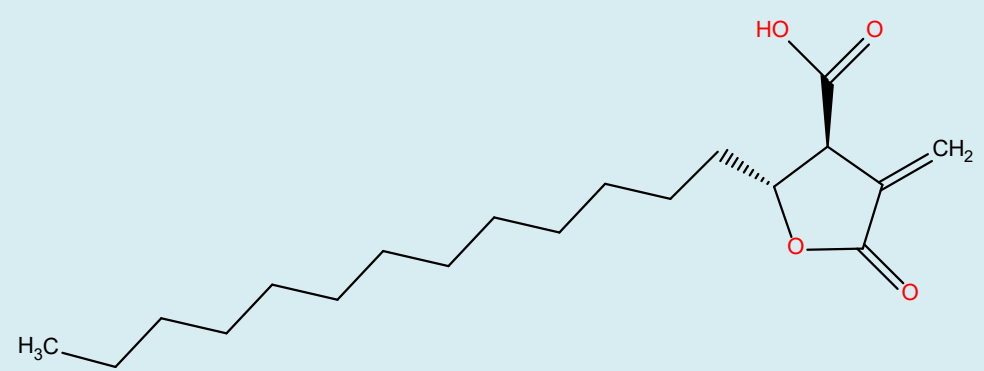

Protolichesterinic acid

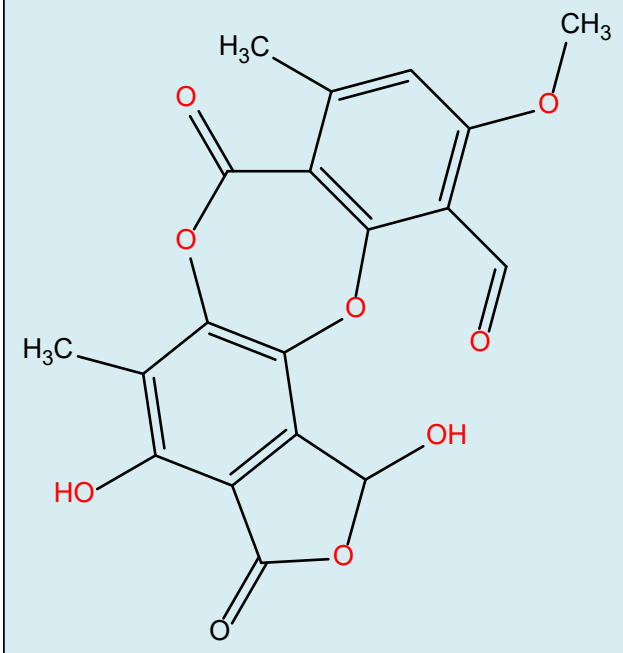

Stictic acid

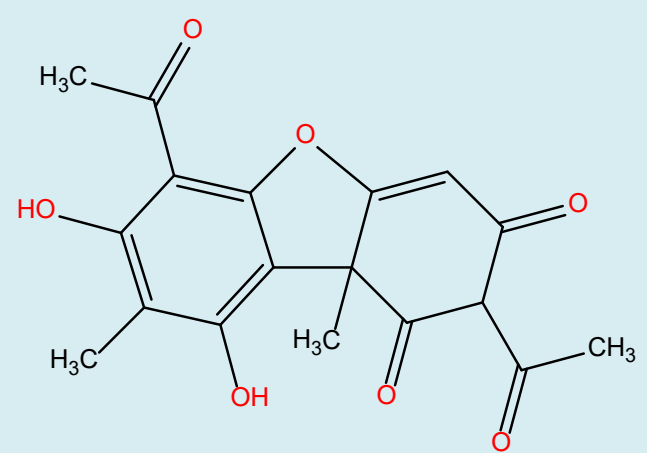

Usnic acid

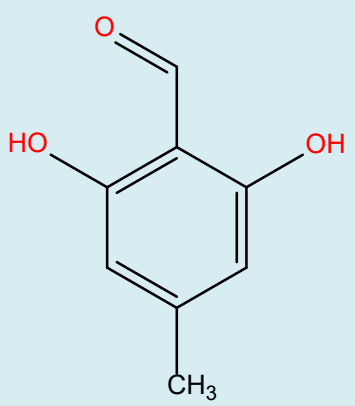

Resorcinol

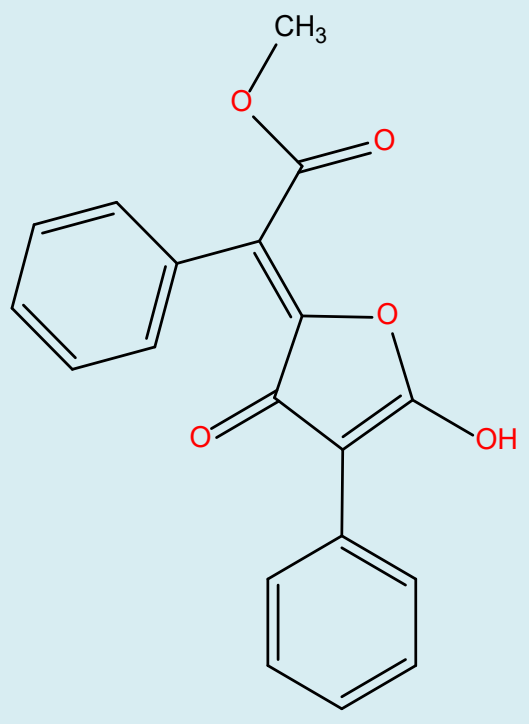

Vulpinic acid

Figure 1: The chemical structures of some common lichens compounds. 


\section{Open Access Journal of Microbiology \& Biotechnology}

Lichens have been known since ancient times for their medical importance. Many lichens were reported to show their effectiveness against restoring lost hair, rabies jaundice, and coughs [22]. During middle age, lichens gained a great value among the herbals used by practitioners. Moreover, lichens are still valuable and important in the modern pharmaceutical industry due to their biological activities [20]. Among the lichens that have gained importance by the people of Northern California is Letharia vulpina (L.) Hue. (Parmeliaceae), this lichen had been used to treat stomach diseases [23]. Another species named Dictyonema was widely consumed by the Waorani as a hallucinogen [24]. However, Alectoria usneoides was used in Arabian medicine for the treatment of enlarged spleen (splenomegaly). Usnea sp. gained a great value for its demulcent properties where it was used in treatments of inflammation of the oral and pharyngeal mucosa. Also, Usnea filipendula Stirt had been used for treatment of cuts and wounds [25]. The Decoction of Pseudoevernia furfuracea (L.) Zopf. (Parmeliaceae) has been consumed in Alfacar and Viznar in respiratory ailments. Other lichens also have been used to treat some kidneyrelated problems such as Ramalina bourgeana Mont. ex Nyl. (Ramalinaceae) that has been consumed as a diuretic and it has been also used to dissolve kidney stones [26].

Numerous commercial pharmacological products containing lichen substances have been developed in many countries all over the world. For example, lichen extracts or substances have been applied in many pharmaceuticals, cosmetics, and neutraceutical products in Japan (Figures 2 \& 3). Icelandic lichens have been consumed in cold remedies formulation under the trade names of Broncholind (MCM Klosterfrau Vertriebsgesellschaft $\mathrm{mbH}$, Germany) and IslaMoos ${ }^{\circledR}$ (Engelhard Arzneimittel GmbH \& Co. KG, Germany). Moreover, usnic acid has been used in some antiseptic products in Italy such as 'Gessato ${ }^{\mathrm{TM}}$ shaving' and in Germany such as 'Camillen 60 Fudes spray and nail oil [27].

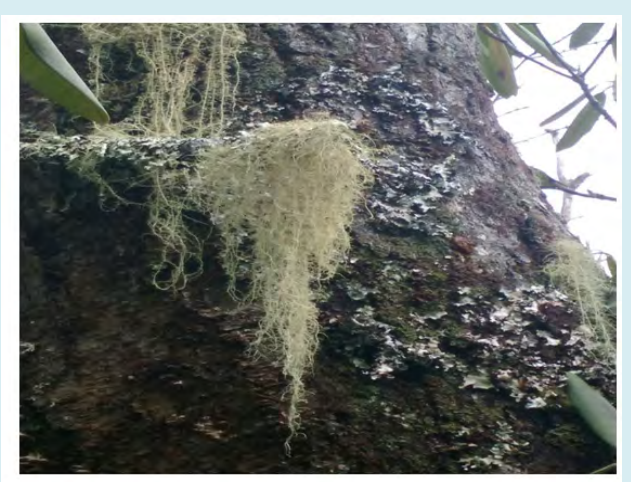

Figure 2: Usnea sp. Family Parmeliaceae, Collected by: Tilson; Locality United States, Virginia, Abingdon, USA. Hosted by; http://mycoportal.org).

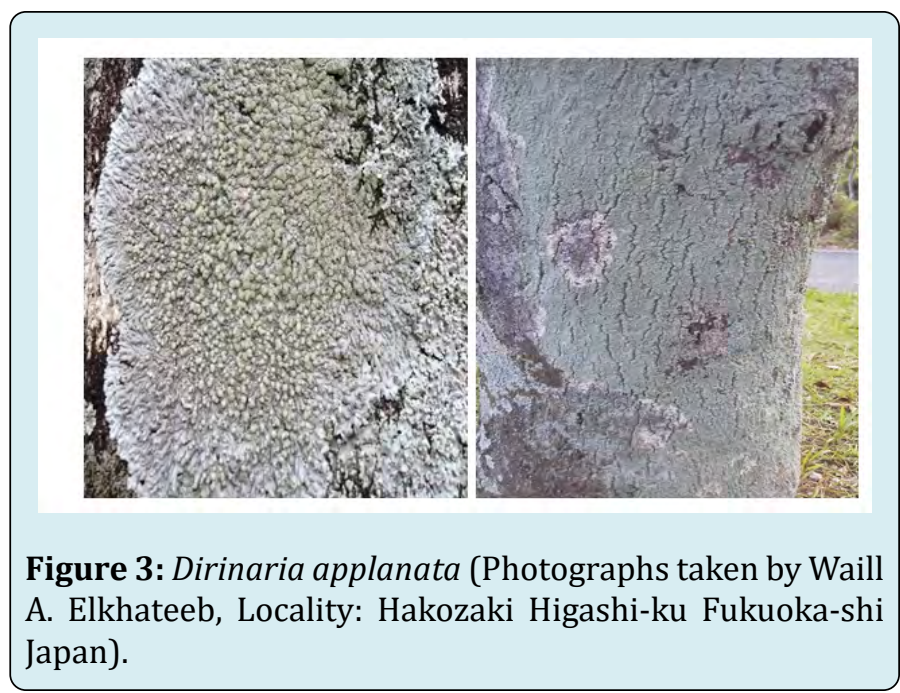

\section{Different Biological Activities of Lichens}

As mentioned before, lichens have highly valued due to their ability to produce a wide variety of vital biologically active primary and secondary metabolites [28-30]. Among the primary metabolites are amino acids, carotenoids, polysaccharides, polyols, and vitamins, etc. Lichenan and isolichenan, are examples of cell wall polysaccharides and both have taxonomic significances. Moreover, the carotenoid compounds produced by lichens have been studied for evolutionary relationships investigation. On the other side, lichen's secondary metabolites, which are usually named lichen acids, are mainly produced by the mycobiont, the secreted onto lichen's hyphae surface either in crystals or amorphous forms. Many studies reported that these secondary metabolites show important biological activities such as antiinflammatory, analgesic, antipyretic, plant growth inhibitory, antibiotic, antimycobacterial, antiviral, enzyme inhibitory, antiproliferative, and cytotoxic effects, as well as many other important biological activities [31].

\section{Antibacterial Activities of Lichens}

The development of resistance to many antibiotics as well as many antimicrobial agents has been a serious problem worldwide [32]. Many pathogenic microbes cause serious threats to human health and more effort have been directed toward this issue. Thus, new alternatives for fighting the spread of infection due to the development of antibiotic-resistant microbes are required. Discovering new natural products are proposed as a new strategy to overcome antibiotic-resistant problems [33,34]. Some lichens-derived substances have exerted antibacterial [35] and interestingly about $50 \%$ of all lichens have been reported to exhibit promising antibiotic activities [27,36]. Burkholder, et al. [37] was the first to conduct a research on lichens as antibacterial agents. Usnic acid is among the lichens-derived products 


\section{Open Access Journal of Microbiology \& Biotechnology}

that have been reported as a strong antimicrobial agent [38]. Additionally, usnic acid as well as others including evernic acid and vulpinic acid can inhibit the growth of various Gram-positive bacteria such as Bacillus subtilis and Bacillus megaterium, as well as Staphylococcus aureus; however, they did not show any effect against Gram-negative bacteria including Escherichia coli nor Pseudomonas aeruginosa [35]. Salazinic acid obtained from acetone, chloroform, diethyl ether, methanol and petroleum ether extracts of Parmelia sulcata has also been reported for its antibacterial activity against various species such as Aeromonas hydrophila, Bacillus subtilis, Bacillus cereus, Listeri monocytogenes, Proteus vulgaris, Staphylococcus aureus, Streptococcus faecalis, Candida albicans Candida glabrata, and Yersinia enterocolitica [39]. Moreover, the ethanol, diethyl ether, and acetone extracts of Cetraria aculeate showed the presence of protolichesterinic acid that exhibits antibacterial activity against some bacteria belonging to both Gram-negative and Gram-positive groups [40]. These bacteria include Bacillus, Candida, E. coli, Kleibsiella, Proteus, Pseudomonas, Salmonella, Staphylococcus aureus, and Yersinia species [41-47].

\section{Antifungal Activities of Lichens}

Many lichens have shown their ability to inhibit fungal growth. The lichens produce many active compounds that possess antifungal activity. These compounds include: atranorin, salanizic acid, stictic acid, usnic acid, divaricatic acid, zeorin, lecanoric acid, lichenic acid, protolichesterinic acid, fumarprotoacetraric acid, and protocetraric acid. Both acetone and methanol extracts of Parmelia sulcata Taylor, Umbilicaria crustulosa (Ach.) Frey and Lasallia pustulata (L.) Méret have been reported to contain selective antifungal agents [47]. Additionally, usnic acid together with 5-propylresorcinol, divaricatinic acid, and isodivaricatic acid showed their ability to inhibit fungal growth [48]. Salazinic acid was extracted from Parmelia sulcate by various solvents such as acetone, diethyl ether, methanol, chloroform, and petroleum ether. Salazinic acid exhibits antifungal activity against some fungi species such as Aspergillus fumigatus, Aspergillus Niger, and Penicillium notatum extracts of containing [39]. Moreover, the methanol extract of Caloplaca cerina (Ehrh. ex Hedwig) Th.Fr. was reported to contain both parietin and anthraquinone that exhibit promising antifungal activities [49].

Acetone extracts obtained from the three lichen species - Cladonia portentosa, Evernia prunastri, and Hypogymnia physodes- also displayed antifungal activity against many plant pathogenic fungi including Botrytis cinerea, Colletotrichum lindemuthianum, Fusarium solani, Pythium ultimum, Phytophthora infestans, Rhizoctonia solani, Stagonospora nodorum, and Ustilago maydis [50]. A powerful antifungal agent named lecanoric acid was isolated from a lichen species 'Parmotrema tinctorum', this is an antifungal agent is very effective against Cladosporium sphaerospermum [19].

\section{Antiviral Activities of Lichens}

Antiviral activities have been attributed to many lichensderived compounds. Anthraquinones, particularly, the polyphenolic and polysulphonate substituted compounds, have been proved to exert promising antiviral properties [51,52]. A previous study reported by Cohen, et al. [53], showed that some lichen-derived compounds such as anthraquinones, hyperacin as well as bianthrones showed antiviral properties. Moreover, the antiviral activity was found to be directly related to the increase in the chlorine substitution in the anthraquinone structure. Since many plants originated polysaccharides exhibit potent antiviral activities, in particular against enveloped viruses [54-56], it was essential to evaluate the antiviral activities of the polysaccharides derived from various lichens. The studies reported that crude polysaccharide isolated from Parmelia perlata lichen showed a potent antiviral activity towards yellow fever virus (the enveloped positive-sense RNA virus), however, it was not active against non-enveloped RNA viruses such as IBDV and poliomyelitis.

Parietin isolated from Ramalina celastri and usnic acid derived from Teloschistes chrysophthalmus (L.) Th. Fr. displayed potent antiviral activity against the arenaviruses, Tacaribe and Junin [57]. It worth mentioning that both the aqueous and the ethanolic extracts of lichen species Xanthoparmelia tinctina and Xanthoria parietina and were tested for their antiviral activity against human parainuenza virus type 2 (HPIV-2) and cytotoxic activity against Vero cells. Xanthoparmelia tinctina ethanol extract showed antiviral activity against HPIV-2 where the half-maximal effective concentration $\left(\mathrm{EC}_{50}\right)$ for the virus replication was $20 \mu \mathrm{g} / \mathrm{mL}$, and for aqueous extract, the $\mathrm{EC}_{50}$ was found to be $22.5 \mu \mathrm{g} / \mathrm{mL}$ [58]. Lichenan is a structural polysaccharide of the mycosymbiont cell wall [59]. It is composed of a linear $(1 \rightarrow 3,1 \rightarrow 4) \beta$-d-glucan linkage [60]. Interestingly, lichenan protects greenhouse-grown various Nicotiana species from the virus accumulation and symptom development caused by a tobacco mosaic virus [61].

\section{Insecticidal Properties of Lichens}

Iinsecticidal agents based on synthetic chemicals are the most commonly used agents against insects. However, these agents show many drawbacks due to the development of chemical resistance resulted from their repeated use. Another serious issue is the development of many health problems due to the bad effect of these agents on food and the environment [62]. One of the successful ways for 


\section{Open Access Journal of Microbiology \& Biotechnology}

getting rid of the mosquito population in breeding grounds before they reach the adult stage is achieved by killing the larvae of mosquitoes [63]. The studies reported that several phytochemicals contain compounds that may be used as alternative sources for harmful synthetic chemicalsbased control agents. Extract obtained from lichen species 'Letharia vulpine' showed a strong insecticidal effect against Spodoptera littoralis and Spodoptera ornithogalli [20]. The results also showed that usnic acids isolated from lichens also show insecticidal effects against Culex pipiens larvae [64].

\section{Antioxidant Activities of Lichens}

Antioxidants are compounds that inhibit the oxidation process. Oxidation is a chemical reaction that results in the production of free radicals which lead to undesired chain reactions and that finally ends in cell damage and degenerative diseases. Natural antioxidants are a better choice for therapeutic use over synthetic antioxidants that could be toxic or have serious side effects. Numerous lichen extracts have demonstrated antioxidant properties due to their phenolic compounds and/or polysaccharides that are well known to exhibit antioxidant properties $[65,66]$. The extracts from Antarctic lichens were reported to display antioxidant activities that were more potent than those obtained from lichens native to tropical regions [32]. However, the phenolic components obtained from the lichen Parmotrema stuppeum (Nyl.) Hale such as atranorin, methyl orsenillate, orsenillic acid, and lecanoric acid showed moderate antioxidant activity [67]. A previous study reported antioxidant activity of lichen Cetraria islandica [68], where that antioxidant activity was assessed by DPPH $(1,1-$ diphenyl-2-picrylhydrazyl) free radical, reducing power, and superoxide anion scavenging activities capacities and compared to positive controls such as BHA (butylated hydroxyanisole) and $\alpha$-tocopherol, quercetin [68]. Also, it was reported that stactic acid derivatives obtained from Usnea articulate lichens displayed potent antioxidant activity [69]. Other lichens interestingly showed antioxidant activities with more than $85 \%$ DPPH scavenging activity. These lichens included Peltigera canina, Peltigera praetextata, Parmotrem pseudotinctorum Ramalina conduplicans, Sticta nylanderiana, and Usnea ghttensis [70].

\section{Antitumor Activities of Lichens}

The effect of lichen extracts on tumors has been extensively studied for many years. Some lichen derived compounds such as cristazarin, usnic acid, depsidone, lichenin, protolichesterinic acid, and polyporic acid exhibited antitumor activities against various tumor cells such as P388 leukemia [71], melanoma B-16 [20], Ehrlich solid tumor [72], K-562 leukaemia [73], and lymphocyte cells [74]. Collema flaccidum extract revealed anticancer activity when evaluated in the crown gall tumor inhibition test. It was reported that colleflaccinosides and bisanthraquinone glycosides were the inhibitors [75]. Also, extracts containing depsidone pannarin showed anticancer activities by inducing cell apoptosis in human melanoma M14 cells, causing cell death in human prostate carcinoma DU-145 cells $[76,77]$.

Usnic acid which is among the important metabolites produced by lichens had an antiproliferative effect on endometrial carcinoma (Ishikawa, HEC-50) cells and human leukemia cells (K562) [78,79]. The polysaccharides derived from lichens also play a role in the antitumor activities of lichens.A lichen-derived polysaccharide named CFP-2 was able to reduce the viability of K562 and HL-60 cancer cells due to telomerase activity and apoptotic pathway, indicating that this polysaccharide could be a promising therapeutic agent against various types of cancer [80].

Methyl orsellinate and tenuiorin that have been isolated from Peltigera leucophlaebia lichen showed their ability to inhibit the proliferative of different cell lines including pancreatic (PANC-1), human breast (T-47D), and colon (WIDR) [38]. Lecanoric acid is a secondary metabolite isolated from Parmotrema timctorum lichen. This metabolite showed anticancer activities against MCF7 breast carcinoma, 786-0 kidney carcinoma, and HEp-2 larynx carcinoma, as well as B16-F10 murine melanoma cell lines [81]. The anticancer properties of other lichens derived substances have been also reported by Huneck [82], Ingolfsdottir, et al. [83] and Elkhateeb, et al. [84].

\section{Conclusion}

Lichens are a generous source of novel compounds that can be investigated for their potential biological activities. This review presents some lichen-derived substances that exhibit a huge array of important biological activities. Many secondary metabolites isolated from lichens showed antibacterial, antifungal, antiviral, insecticidal, antioxidant as well as antitumor activities. Furthermore, the properties of these lichen-derived substances make them of great value to be applied in many pharmaceutical industries. At the same time, it is well known that lichens are slow-growers, and the exploitation of their valuable secondary metabolites could threaten the survival of lichens. Thus, improving the culture methods and adjusting the growing conditions might extensively improve the production of these secondary metabolites without being at risk of the extinction of the natural communities.

\section{References}

1. Elkhateeb WA, Thomas P, Daba GM, Sheir D, Kalani K, 


\section{Open Access Journal of Microbiology \& Biotechnology}

et al. (2020) Mysterious World of Lichens: Highlights on Their History, Applications, and Pharmaceutical Potentials. The Natural Products Journal 10: 1-13.

2. Seymour FA, Crittenden PD, Dickinson MJ, Paoletti M, Montiel D, et al. (2005) Breeding systems in the lichenforming fungal genus Cladonia. Fungal Genetics and Biology 42(6): 554-563.

3. Ranković B (2015) Lichen secondary metabolites. Springer International Publishing, Cham.

4. Clair SB, Clair LL, Weber DJ, Mangelson N, Eggett D (2002) Element accumulation patterns in foliose and fruticose lichens from rock and bark substrates in Arizona. The Bryologist 105(3): 415-421.

5. Solhaug KA, Lind M, Nybakken L, Gauslaa Y (2009) Possible functional roles of cortical depsides and medullary depsidones in the foliose lichen Hypogymnia physodes. Flora-Morphology, Distribution, Functional Ecology of Plants 204(1): 40-48.

6. Nayaka S (2014) Methods and techniques in collection, preservation and identification of lichens. Plant Toxonomy and Biosystematics: Classical and Modern Methods, pp: 101-105.

7. Monge-Nájera J (2019) Relative humidity, temperature, substrate type, and height of terrestrial lichens in a tropical paramo. Revista de Biología Tropical 67(1): 206-212.

8. Feuerer T, Hawksworth DL (2007) Biodiversity of lichens, including a world-wide analysis of checklist data based on Takhtajan's floristic regions. Biodiversity and conservation 16(1): 85-98.

9. Elkhateeb WA, Daba GM (2019) Lichens, an alternative drugs for modern diseases. Int J Res Pharm Biosci 6: 5-9.

10. Galun M (1988) CRC handbook of lichenology, $1^{\text {st }}$ (Edn.), CRC press, pp: 148.

11. Richardson DH (1988) Medicinal and other economic aspects of lichens. CRC handbook of lichenology 3: 93.

12. Shukla V, Joshi G, Rawat M (2010) Lichens as a potential natural source of bioactive compounds: a review. Phytochem Rev 9: 303-314.

13. Molnár K, Farkas E (2010) Current results on biological activities of lichen secondary metabolites: a review. Z Naturforsch C J Biosci 65(3-4): 157-173.

14. Elkhateeb WA, Daba GM (2020) Occurrence of terpenes, polyketides, and tannins in some Japanese lichens and green mosses. Egyptian Pharmaceutical Journal 19(3): 216-223.

15. Shrestha G, Clair LL (2013) Lichens: a promising source of antibiotic and anticancer drugs. Phytochemistry Reviews 12(1): 229-244.

16. Vartia KO (1973) Antibiotics in lichens. The lichens, Elsevier, pp: 547-561.

17. Elix JA (1996) A revision of the lichen genus Relicina, pp: 150.

18. Nash TH (1996) Lichen biology, $2^{\text {nd }}$ (Edn.), Cambridge University Press.

19. Gomes AT, Honda N, Roese FM, Muzzi RM, Marques MR (2002) Bioactive derivatives obtained from lecanoric acid, a constituent of the lichen Parmotrema tinctorum (Nyl.) Hale (Parmeliaceae). Revista Brasileira de Farmacognosia 12: 74-75.

20. Khanuja S, Tiruppadiripuliyur R, Gupta V, Chand P, Garg A, et al. (2003) Antimicrobial and anticancer properties of methyl-beta-orcinolcarboxylate from lichen (Everniastrum cirrhatum). Pubchem US20070099993-A1.

21. Ranković B, Mišić M (2008) The antimicrobial activity of the lichen substances of the lichens Cladonia furcata, Ochrolechia androgyna, Parmelia caperata and Parmelia conspresa. Biotechnology \& Biotechnological Equipment 22(4): 1013-1016.

22. Pereira J (1843) The elements of materia medica and therapeutics. Lea and Blanchard, Philadelphia.

23. Malhotra S, Subban R, Singh A (2008) Lichens-role in traditional medicine and drug discovery. The Internet Scientific Publications 5(2): 1-5.

24. Davis EW, Yost J (1983) Novel hallucinogens from eastern Ecuador. Botanical Museum Leaflets. Harvard University 29(3): 291-295.

25. Chevallier A (1996) Encyclopedia of medicinal plants. Dorling kindersley pty limited, St Leonards. New South Wales.

26. Gonzalez-Tejero M, Martinez-Lirola M, Casares-Porcel M, Molero-Mesa J (1995) Three lichens used in popular medicine in Eastern Andalucia (Spain). Economic Botany 49: 96-98.

27. Zambare VP, Christopher LP (2012) Biopharmaceutical potential of lichens. Pharm Biol 50(6): 778-798. 


\section{Open Access Journal of Microbiology \& Biotechnology}

28. Lauterwein M, Oethinger M, Belsner B, Peters T, Marre $\mathrm{R}$ (1995) In vitro activities of the lichen secondary metabolites vulpinic acid,(+)-usnic acid, and (-)-usnic acid against aerobic and anaerobic microorganisms. Antimicrobial agents and chemother 39(11): 25412543.

29. Müller K (2001) Pharmaceutically relevant metabolites from lichens. Appl microbiol biotechnol 56(1-2): 9-16.

30. Boustie J, Grube M (2005) Lichens--a promising source of bioactive secondary metabolites. Plant Genetic Resources 3(2): 273-287.

31. Shawuti G, Abbas A (2007) Research progress on biological activities of lichens secondary metabolites. Food Science 10: 160.

32. Paudel B, BhattaraiH, Lee S, Hong S, Shin S, et al. (2008) Antibacterial potential of Antarctic lichens against human pathogenic Gram-positive bacteria. Phytother Res 22(9): 1269-1271.

33. Ali M, Azhar I, Amtul Z, Ahmad V, Usmanghani K (1999) Antimicrobial screening of some Caesalpiniaceae. Fitoterapia 70(3): 299-304.

34. Nimri LF, Meqdam M, Alkofahi A (1999) Antibacterial activity of Jordanian medicinal plants. Pharmaceutical biology 37(3): 196-201.

35. Lawrey JD (1986) Biological role of lichen substances. Bryologist 89(2): 111-122.

36. Sharnoff SD (1997) Lichens and people.

37. Burkholder PR, Evans A, McVeigh A, Thornton H (1944) Antibiotic Activity of Lichens. Proc Natl Acad Sci USA 30(9): 250-255.

38. Ingólfsdóttir K, Gudmundsdóttir GF, Ögmundsdóttir HM, Paulus K, Haraldsdóttir S, et al. (2002) Effects of tenuiorin and methyl orsellinate from the lichen Peltigera leucophlebia on 5-/15-lipoxygenases and proliferation of malignant cell lines in vitro. Phytomedicine 9(7): 654658.

39. Candan M, Yllmaz M, Tay T, Erdem M, Türk AO (2007) Antimicrobial activity of extracts of the lichen Parmelia sulcata and its salazinic acid constituent. Z Naturforsch C J Biosci 62(7-8): 619-621.

40. Türk AÖ, Yılmaz M, Kıvanç M, Türk H (2003) The antimicrobial activity of extracts of the lichen Cetraria aculeata and its protolichesterinic acid constituent. Z Naturforsch C J Biosci 58(11-12): 850-854.
41. Ingolfsdottir K, Bloomfield S, Hylands P (1985) In vitro evaluation of the antimicrobial activity of lichen metabolites as potential preservatives. Antimicrob Agents and Chemother 28(2): 289-292.

42. Tay T, Türk AO, Yılmaz M, Türk H, Kıvanç M (2004) Evaluation of the antimicrobial activity of the acetone extract of the lichen Ramalina farinacea and its (+)-usnic acid, norstictic acid, and protocetraric acid constituents. Z Naturforsch C J Biosci 59(5-6): 384-388.

43. Yllmaz M, Türk AO, Tay T, Kıvanç $M$ (2004) The antimicrobial activity of extracts of the lichen Cladonia foliacea and its (-)-usnic acid, atranorin, and fumarprotocetraric acid constituents. Z Naturforschung C J Biosci 59(3-4): 249-254.

44. Karagouml A, Doğruouml N, Zeybek Z, Aslan A (2009) Antibacterial activity of some lichen extracts. Journal of Medicinal Plants Research 3(12): 1034-1039.

45. Karthikaidevi G, Thirumaran G, Manivannan K, Anantharaman P, Kathiresan K, et al. (2009) Screening of the antibacterial properties of lichen Roccella belangeriana (Awasthi) from Pichavaram mangrove (Rhizophora sp.). Adv Biol Res 3(3-4): 127-131.

46. Manojlovic N, Vasiljevic P, Markovic ZS (2010) Antimicrobial activity of extracts and various fractions of chloroform extract from the lichen Laurera benguelensis. Journal of Biological Research 13: 27-34.

47. Martins MC, Lima M, Silva F, Azevedo-Ximenes E, Silva $\mathrm{N}$, et al. (2010) Cladia aggregata (lichen) from Brazilian northeast: chemical characterization and antimicrobial activity. Braz. arch. biol. technol 53(1): 115-122.

48. Ranković B, Mišić M, Sukdolak S (2007) Evaluation of antimicrobial activity of the lichens Lasallia pustulata, Parmelia sulcata, Umbilicaria crustulosa, and Umbilicaria cylindrica. Microbiologiia 76(6): 817-821.

49. Manojlovic NT, Solujic S, Sukdolak S, Milosev M (2005) Antifungal activity of Rubia tinctorum, Rhamnus frangula and Caloplaca cerina. Fitoterapia 76(2): 244-246.

50. Halama P, Van Haluwin C (2004) Antifungal activity of lichen extracts and lichenic acids. BioControl 49(1): 95107.

51. Schinazi RF, Chu C, Babu J, Oswald B, Saalmann V, et al. (1990) Anthraquinones as a new class of antiviral agents against human immunodeficiency virus. Antiviral Res 13(5): 265-272.

52. Sydiskis R, Owen DG, Lohr JL, Rosler KH, Blomster RN (1991) Inactivation of enveloped viruses by 


\section{Open Access Journal of Microbiology \& Biotechnology}

anthraquinones extracted from plants. Antimicrob Agents Chemother 35(12): 2463-2466.

53. Cohen PA, Hudson JB, Towers GH (1996) Antiviral activities of anthraquinones, bianthrones and hypericin derivatives from lichens. Experientia 52(2): 180-183.

54. Hosoya M, Balzarini J, Shigeta S, De Clercq E (1991) Differential inhibitory effects of sulfated polysaccharides and polymers on the replication of various myxoviruses and retroviruses, depending on the composition of the target amino acid sequences of the viral envelope glycoproteins. Antimicrob Agents Chemother 35(12): 2515-2520.

55. Premanathan M, Kathiresan K, Yamamoto N, Nakashima $H$ (1999) In vitro anti-human immunodeficiency virus activity of polysaccharide from Rhizophora mucronata Poir. Biosci Biotechnol Biochem 63(7): 1187-1191.

56. Yu Y, Shen M, Song Q, Xie J (2018) Biological activities and pharmaceutical applications of polysaccharide from natural resources: A review. Carbohydrate polymers 183: 91-101.

57. Fazio AT, Adler M, Bertoni D, Sepúlveda C, Damonte EB, et al. (2007) Lichen secondary metabolites from the cultured lichen mycobionts of Teloschistes chrysophthalmus and Ramalina celastri and their antiviral activities. Z Naturforsch C J Biosci 62 (7-8): 543549.

58. Karagoz A, Aslan A (2005) Antiviral and cytotoxic activity of some lichen extracts. BIOLOGIA 60(3): 281-286.

59. Honegger R, Haisch A (2001) Immunocytochemical location of the $(1 \rightarrow 3)(1 \rightarrow 4)$ - $\beta$-glucan lichenin in the lichen-forming ascomycete Cetraria islandica (Icelandic moss). New phytologist 150(3): 739-746.

60. Tvaroska I, Ogawa K, Deslandes Y, Marchessault RH (1983) Crystalline conformation and structure of lichenan and barley $\beta$-glucan. Can J Chem 61(7): 16081616.

61. Stübler D, Buchenauer H (1996) Antiviral Activity of the Glucan Lichenan (Poly- $\beta(1 \rightarrow 3,1 \rightarrow 4)$ D-anhydroglucose) 1. Biological Activity in Tobacco Plants. Journal of Phytopathology 144(1): 37-43.

62. Bonning BC, Hammock BD (1992) Development and potential of genetically engineered viral insecticides. Biotechnol Genet Eng Rev 10: 455-489.

63. Vinayaka KS, Kumar P, Kekuda P, Krishnamurthy YL, Mallikarjun N, et al. (2009) Proximate composition, antioxidant, anthelmintic and insecticidal activity of a macrolichen Ramalina conduplicans Vain. (Ramalinaceae). European Journal of Applied Sciences 1(3): 40-46.

64. Cetin H, Tufan-Cetin O, Turk OA, Tay T, Candan M, et al. (2008) Insecticidal activity of major lichen compounds,(-)-and (+)-usnic acid, against the larvae of house mosquito, Culex pipiens L. Parasitol Res 102(6): 1277-1279.

65. Hidalgo ME, Fernandez E, Quilhot W, Lissi E (1994) Antioxidant activity of depsides and depsidones. Phytochemistry 37(6): 1585-1587.

66. Liu F, Ooi V, Chang S (1997) Free radical scavenging activities of mushroom polysaccharide extracts. Life sci 60(10): 763-771.

67. Jayaprakasha GK, Rao LJ (2000) Phenolic constituents from the lichen Parmotrema stuppeum (Nyl.) Hale and their antioxidant activity. Z Naturforsch C J Biosci 55(1112): 1018-1022.

68. Gülçin İ, Oktay M, Küfrevioğlu OI, Aslan A (2002) Determination of antioxidant activity of lichen Cetraria islandica (L) Ach. J Ethnopharmacol 79(3): 325-329.

69. Lohézic-Le Dévéhat F, Tomasi S, JElix JA, Bernard A, Rouaud I Uriac P, et al. (2007) Stictic acid derivatives from the lichen Usnea articulata and their antioxidant activities. J Nat Prod 70(7): 1218-1220.

70. Kosanić M, Ranković B, Vukojević J (2011) Antioxidant properties of some lichen species. J Food Sci Technol 48(5): 584-590.

71. Takai M, Uehara Y, BeislerJA (1979) Usnic acid derivatives as potential antineoplastic agents. J Med Chem 22(11): 1380-1384.

72. Cain BF (1966) Potential anti-tumour agents. Part IV. Polyporic acid series. J Chem Soc perkin 11: 1041-1045.

73. Hirayama T, Fujikawa F, Kasahara T, Otsuka M, Nishida $\mathrm{N}$, et al. (1980) Anti-tumor activities of some lichen products and their degradation products (author's transl). Yakugaku Zasshi 100(7): 755-759.

74. Correche E, Carrasco M, Giannini F, Piovano M, Garbarino J, et al. (2002) Cytotoxic screening activity of secondary lichen metabolites. Acta Farm Bonaerense 21(4): 273278.

75. Řezanka T, Dembitsky V (2006) The colleflaccinosides, two chiral bianthraquinone glycosides with antitumor activity from the lichen Collema flaccidum collected in Israel and Russia. Nat Prod Res 20(10): 969-980. 


\section{Open Access Journal of Microbiology \& Biotechnology}

76. Maier MS, González Marimon D, Stortz M, Adler A (1999) A revised structure for (-)-Dihydropertusaric acid, a $\gamma$-butyrolactone acid from the lichen Punctelia microsticta. J Nat Prod 62(11): 1565-1567.

77. Russo A, Piovano M, Lombardo L, Vanella L, Cardile V, et al. (2006) Pannarin inhibits cell growth and induces cell death in human prostate carcinoma DU-145 cells. Anticancer Drugs 17(10): 1163-1169.

78. Cardarelli M, Serino G, Campanella L, Ercole P, Nardone F, et al. (1997) Antimitotic effects of usnic acid on different biological systems. Cellular and Molecular Life Sciences CMLS 53(8): 667-672.

79. Kristmundsdóttir $\mathrm{T}$, Aradóttir HA, Ingólfsdóttir $\mathrm{K}$, Ögmundsdóttir HM (2002) Solubilization of the lichen metabolite (+)-usnic acid for testing in tissue culture. J Pharm Pharmacol 54(11): 1447-1452.

80. Lin X, Cai YJ, Li ZX, Chen Q Liu ZL, et al.(2003) Structure determination, apoptosis induction, and telomerase inhibition of CFP-2, a novel lichenin from Cladonia furcata. Biochim Biophys Acta 1622(2): 99-108.

81. Bogo D, Matos M, Honda N, Pontes E, Oguma P, et al. (2010) In vitro antitumour activity of orsellinates. Z Naturforsch C J Biosci 65(1-2): 43-48.

82. Huneck S (2001) New results on the chemistry of lichen substances. Fortschr Chem Org Naturst 81: 1-276.

83. Ingolfsdottir $\mathrm{K}$, Hjalmarsdottir MA, Sigurdsson $\mathrm{A}$, Gudjonsdottir GA, Brynjolfsdottir A, et al. (1997) In vitro susceptibility of Helicobacter pylori to protolichesterinic acid from the lichen Cetraria islandica. Antimicrob Agents Chemother 41(1): 215-217.

84. Elkhateeb WA, Daba GM, El-Dein A, Sheir DH, Fayad W, et al. (2020) Insights into the in-vitro hypocholesterolemic, antioxidant, antirotavirus, and anticolon cancer activities of the methanolic extracts of a Japanese lichen, Candelariella vitellina, and a Japanese mushroom, Ganoderma applanatum. Egyptian Pharmaceutical Journal 19(1): 67-73. 